\title{
Inflammation of the cerebral arteries: lifting the veil on the pathobiology of intracranial aneurysms
}

\author{
Dale Ding \\ Department of Neurosurgery, University of Virginia, Charlottesville, VA 22908, USA.
}

Cerebral aneurysms (CAs) are the most common cause of spontaneous subarachnoid hemorrhage $(\mathrm{SAH}) .^{[1]}$ Despite significant improvements in microsurgical and endovascular aneurysm therapies and in neurocritical care since the turn of the century, the outcomes after CA rupture remain dismal. The mortality associated with aneurysmal SAH is approximately $50 \%$, and of the survivors, approximately one-third have long-term neurocognitive deficits and one-half require permanent assistance. ${ }^{[2,3]}$ Since post-SAH management outcomes have seemingly plateaued in the past decade, the ideal window for improving overall outcomes in CA patients is prior to rupture. ${ }^{[4]}$

However, interventions for unruptured CAs are not without risk, so their risk to benefit profiles must be compared to the natural history of unruptured CAs. ${ }^{[5,6]}$ Naggara et al. ${ }^{[7]}$ performed a systematic review of endovascular treatment outcomes for unruptured CAs and found a 5\% rate of unfavorable outcomes. Similarly, Kotowski et $a{ }^{\left[{ }^{[8]}\right.}$ performed a systematic review of surgical outcomes for unruptured CAs and reported a $7 \%$ rate of unfavorable outcomes. Even as advances in neurointerventional techniques and endovascular technologies, including newer generation flow-diverting stents (i.e. Surpass, flow redirection endoluminal device), intermediate coverage stents (i.e. LVIS), aneurysm neck and bifurcation reconstruction devices (i.e. PulseRider, Barrel, Eclips), and intrasaccular flow disruptors (i.e. WEB, Luna),

\begin{tabular}{|l|l|}
\hline \multicolumn{3}{|c|}{ Access this article online } \\
\hline Quick Response Code: & \\
\hline & \\
\hline
\end{tabular}

continue to improve interventional outcomes for CAs, treatment of unruptured CAs continues to expose patients to potential morbidity and mortality. ${ }^{[9,10]}$ Therefore, a medical therapy that effectively reduces the hemorrhage risk of an unruptured CA with a reasonable safety profile may improve the long-term outcomes for patients harboring these lesions. Unfortunately, such a therapy does not currently exist, although the efficacies of novel and existing pharmacologic agents have been investigated..$^{[11]}$

A crucial component to the development of an effective drug to stabilize or induce regression of CAs is acquiring an understanding of their pathogenesis. Two common pathogenic features shared by CAs and extracranial aneurysms are (1) chronic inflammation, with an accompanying increase in the expression of pro-inflammatory cytokines and matrix metalloproteinases, initiates and exacerbates CA development, and (2) progressive loss of smooth muscle cells (SMCs) in an artery's tunica media, which are critical for providing contractility and mechanical stability of the vessel wall. One of the difficulties in evaluating CA pathophysiology is the lack of animal models that accurately recapitulate the human disease. A mouse CA model is advantageous over models in other animals, due to the plethora of different genetic knockouts that are available in mice. An increasingly popular mouse CA model was initially devised by Nuki et al., ${ }^{[12]}$ in which CAs are generated by a combination of induced systemic hypertension and intracranial elastase injection into the basal cisterns. A number of recent studies have used this mouse model to investigate the role of various endogenous factors in CA pathogenesis. ${ }^{[13-16]}$

Inflammation has been shown to be a central contributor to the pathogenesis of CAs. Hasan et al. ${ }^{[17]}$ showed that ferumoxytol-enhanced magnetic resonance

Corresponding Author: Dr. Dale Ding, Department of Neurosurgery, University of Virginia, P.O. Box 800212, Charlottesville, VA 22908, USA. E-mail: dmd7q@virginia.edu 
imaging (MRI) can be used to evaluate inflammation and destabilization of the CA wall by utilizing ferumoxytol uptake as a surrogate indicator of macrophage turnover. More recently, Edjlali et al. ${ }^{[18]}$ found that circumferential enhancement of the CA wall on MRI can identify CAs prone to rupture. Although our knowledge of CA pathobiology has improved significantly over the past decade, there remains much to be learned and tested. One challenge in determining the role of the immune system in CA pathogenesis is the phenotypic plasticity exhibited by SMCs, a unique phenomenon not observed in cardiac and skeletal muscle cells. In the setting of vascular injury or inflammation, SMCs undergo phenotypic modulation, a process by which markers of mature SMCs are downregulated and markers of inflammatory cells, such as macrophages, are upregulated ${ }^{[19]}$ Given the inability of conventional immunohistochemical staining methods to identify transdifferentiated SMCs, evaluation of SMC epigenetic signatures and SMC lineage tracing studies are necessary to accurately assess the contribution of SMCs to vascular lesions, such as CAs. ${ }^{[20]}$ Thus, the respective roles of cells of SMC and myeloid lineage in CA formation, progression, and rupture remains incompletely defined. ${ }^{[21]}$

Despite the current limitations in our understanding of CA pathogenesis, the future of CA translational and clinical research is promising. In this special issue of Neuroimmunology and Neuroinflammation on the topic of "The Role of Inflammation in Cerebral Aneurysms", we have assembled a collection of articles from renowned experts in the field of cerebrovascular disease, and attempt to lift the veil on the pathobiology of intracranial aneurysms.

\section{REFERENCES}

1. Brown RD Jr, Broderick JP. Unruptured intracranial aneurysms: epidemiology, natural history, management options, and familial screening. Lancet Neurol 2014;13:393-404.

2. Hop JW, Rinkel GJ, Algra A, van Gijn J. Case-fatality rates and functional outcome after subarachnoid hemorrhage: a systematic review. Stroke 1997;28:660-4.

3. Mayer SA, Kreiter KT, Copeland D, Bernardini GL, Bates JE, Peery S, Claassen J, Du YE, Connolly ES Jr. Global and domain-specific cognitive impairment and outcome after subarachnoid hemorrhage. Neurology 2002;59:1750-8.

4. Nieuwkamp DJ, Setz LE, Algra A, Linn FH, de Rooij NK, Rinkel GJ. Changes in case fatality of aneurysmal subarachnoid haemorrhage over time, according to age, sex, and region: a meta-analysis. Lancet Neurol 2009;8:635-42.

5. Wiebers DO, Whisnant JP, Huston J 3rd, Meissner I, Brown RD Jr, Piepgras DG, Forbes GS, Thielen K, Nichols D, O'Fallon WM, Peacock J, Jaeger L, Kassell NF, Kongable-Beckman GL, Torner JC; International Study of Unruptured Intracranial Aneurysms Investigators. Unruptured intracranial aneurysms: natural history, clinical outcome, and risks of surgical and endovascular treatment. Lancet 2003;362:103-10.

6. UCAS Japan Investigators, Morita A, Kirino T, Hashi K, Aoki N,
Fukuhara S, Hashimoto N, Nakayama T, Sakai M, Teramoto A, Tominari S, Yoshimoto T. The natural course of unruptured cerebral aneurysms in a Japanese cohort. $N$ Engl $J$ Med 2012;366:2474-82.

7. Naggara ON, Lecler A, Oppenheim C, Meder JF, Raymond J. Endovascular treatment of intracranial unruptured aneurysms: a systematic review of the literature on safety with emphasis on subgroup analyses. Radiology 2012;263:828-35.

8. Kotowski M, Naggara O, Darsaut TE, Nolet S, Gevry G, Kouznetsov E, Raymond J. Safety and occlusion rates of surgical treatment of unruptured intracranial aneurysms: a systematic review and meta-analysis of the literature from 1990 to 2011. J Neurol Neurosurg Psychiatry 2013;84:42-8.

9. Starke RM, Durst CR, Evans A, Ding D, Raper DM, Jensen ME, Crowley RW, Liu KC. Endovascular treatment of unruptured wide-necked intracranial aneurysms: comparison of dual microcatheter technique and stent-assisted coil embolization. $J$ Neurointerv Surg 2015;7:256-61.

10. Starke RM, Turk A, Ding D, Crowley RW, Liu KC, Chalouhi N, Hasan DM, Dumont AS, Jabbour P, Durst CR, Turner RD. Technology developments in endovascular treatment of intracranial aneurysms. JNeurointerv Surg 2014. [DOI: 10.1136/neurintsurg-2014-011475].

11. Hasan DM, Mahaney KB, Brown RD Jr, Meissner I, Piepgras DG, Huston J, Capuano AW, Torner JC. Aspirin as a promising agent for decreasing incidence of cerebral aneurysm rupture. Stroke 2011;42:3156-62.

12. Nuki Y, Tsou TL, Kurihara C, Kanematsu M, Kanematsu Y, Hashimoto T. Elastase-induced intracranial aneurysms in hypertensive mice. Hypertension 2009;54:1337-44.

13. Starke RM, Raper DM, Ding D, Chalouhi N, Owens GK, Hasan DM, Medel R, Dumont AS. Tumor necrosis factor- $\alpha$ modulates cerebral aneurysm formation and rupture. Transl Stroke Res 2014;5:269-77.

14. Peña-Silva RA, Chalouhi N, Wegman-Points L, Ali M, Mitchell I, Pierce GL, Chu Y, Ballas ZK, Heistad D, Hasan D. Novel role for endogenous hepatocyte growth factor in the pathogenesis of intracranial aneurysms. Hypertension 2015;65:587-93.

15. Peña Silva RA, Kung DK, Mitchell IJ, Alenina N, Bader M, Santos RA, Faraci FM, Heistad DD, Hasan DM. Angiotensin 1-7 reduces mortality and rupture of intracranial aneurysms in mice. Hypertension 2014;64:362-8.

16. Starke RM, Chalouhi N, Jabbour PM, Tjoumakaris SI, Gonzalez LF, Rosenwasser RH, Wada K, Shimada K, Hasan DM, Greig NH, Owens GK, Dumont AS. Critical role of TNF- $\alpha$ in cerebral aneurysm formation and progression to rupture. $J$ Neuroinflammation 2014;11:77.

17. Hasan D, Chalouhi N, Jabbour P, Dumont AS, Kung DK, Magnotta VA, Young WL, Hashimoto T, Winn HR, Heistad D. Early change in ferumoxytol-enhanced magnetic resonance imaging signal suggests unstable human cerebral aneurysm: a pilot study. Stroke 2012;43:3258-65.

18. Edjlali M, Gentric JC, Régent-Rodriguez C, Trystram D, Hassen WB, Lion S, Nataf F, Raymond J, Wieben O, Turski P, Meder JF, Oppenheim C, Naggara O. Does aneurysmal wall enhancement on vessel wall MRI help to distinguish stable from unstable intracranial aneurysms? Stroke 2014;45:3704-6.

19. Owens GK. Regulation of differentiation of vascular smooth muscle cells. Physiol Rev 1995;75:487-517.

20. Gomez D, Owens GK. Smooth muscle cell phenotypic switching in atherosclerosis. Cardiovasc Res 2012;95:156-64.

21. Starke RM, Chalouhi N, Ding D, Raper DM, Mckisic MS, Owens GK, Hasan DM, Medel R, Dumont AS. Vascular smooth muscle cells in cerebral aneurysm pathogenesis. Transl Stroke Res 2014;5:338-46.

Cite this article as: Ding D. Inflammation of the cerebral arteries: lifting the veil on the pathobiology of intracranial aneurysms. Neuroimmunol Neuroinflammation 2015;2(2):49-50.

Source of Support: Nil. Conflict of Interest: No.

Received: 19-01-2015; Accepted: 25-01-2015 